\title{
Migration Induced Legal Pluralism in Land Tenure: Implications for Environmental Change
}

Unruh JD (2004) Migration induced legal pluralism in land tenure: implications for environmental change. In: Unruh JD, Krol MS, Kliot N (eds.) Environmental Change and its Implications for Population Migration, Kluwer, Dordrecht, The Netherlands

Jon D. Unruh, Ph.D.

Associate Professor

Department of Geography

McGill University

805 Sherbrooke St W.

Montreal, Quebec

Canada, H3A 2K6

Tel: 514-398-8989

Fax: 514-398-7437

Email: jon.unruh@mcgill.ca 


\begin{abstract}
Migration is expected to be a significant force both resulting from and contributing to environmental change. With significant proportions of migrants seeking access to rural land resources in the pursuit of near term food security, problematic land tenure issues will increasingly be brought to the fore for large numbers of people over significantly large areas. As migration emerges as a global trend, the cultural, ethnic, historical, and social composition of migrants and migrant groups will grow increasingly diverse. The resulting approaches to land tenure involving rights of occupation, use, claim, and disputing will reflect this diversity.

Repercussions for environmental change that arise from increasingly pluralistic approaches to land tenure involve: (1) an increase in the frequency and severity of land disputes together with a much reduced institutional ability for resolution, which leads to a race for resource use and subsequent resource degradation; and, (2) a pronounced reduction in tenure security, leading to short-term exploitation of resources and reduced investments in long-term, sustainable, conservation-oriented land use.
\end{abstract}

\title{
Introduction
}

Increasingly pervasive migration in the developing world is emerging as an important force in global environmental change scenarios (e.g., Amacher et. al., 1998; McGregor 1994; Southgate 1990, Myers 1997; Doos 1994; Ghimire 1994; IUCN 2000). Whether by forced dislocation or self-selected migration, a wide variety of causal factors related to resource conditions, from food insecurity, conflict, and water resources, to political, social and economic disruptions, are increasingly leading to larger scale migrations with significant impacts on the environmental resources needed to sustain livelihoods. Such impacts can then lead to additional dislocation and migration due to resource scarcity and conflict. The impact on natural resources and resource use systems in temporary and permanent destination areas extends beyond direct environmental degradation, leading local (non-migrant) communities to change resource use arrangements due to the presence of significant migrant populations, and governments to search for appropriate policy and enforcement instruments.

Given that a large proportion of migrants in the developing world are rural inhabitants who seek rural destinations (Ghimire 1994), the environmental impact of migrant presence in destination areas operates within the domain of interaction with land based resources and the local communities who have pre-existing claim and use rights to those resources. In this context rural land resource rights (land tenure) play a primary role in how migrants intersect with destination resources and communities, and the resulting environmental consequences. A great deal of valuable work has contributed much to our understanding of the important role of land tenure with regard to how humans interact with the environment (e.g., Katon et al 2001; Ostrom et al., 1999; Amacher et al 1998; Thesihuesen 1991; 
Southgate 1990). And in aggregate land tenure plays a primary role on land cover change at various scales (Unruh 1995a). In a migration context often the first and most important interaction between migrants, and between migrants and local communities, is over access to resources, and most often, the land resources needed for near term food security (e.g. McGregor 1994; Unruh1995a, 1993).

One of the more important emerging aspects of migration in the developing world is the increasing diversity of those who migrate. (McGregor 1994; Schmeidl 1998). McGregor (1994) reviews the literature on migrant and refugee livelihoods, noting that the economic and ecologic changes that take place in destination locations for migrants result in very diverse experiences in different places. Not only are migrants emerging from a wider variety of states and regions within states, but from a wider variety of livelihood systems, religions, ethnic groups, and socioeconomic strata (Schmeidl 1998). As well, the array of specific reasons for dislocation, and the variety of experiences during migration, add to the diversity of migrant characteristics, and importantly, to the diversity of their approaches to resource access in temporary and permanent destination locations. Diversity in tenurial constructs in a migration context comes about both as migrants carry with them notions about property rights arrangements that are familiar, and seek or are compelled to pursue new constructs in new locations.

Due to the diversity of tenurial constructs coming into contact with each other through migration, and the primary role that land tenure issues play in impacts on the environment and environmental change, what is the aggregate land tenure pattern which is likely to emerge as migrants and migrations become more common, complex, and conflictive? And what are likely to be the primary environmental repercussions of this pattern? This paper draws on a literature review and the author's research and policy experience with land tenure, migration, and environmental change conditions in East, Central, and Southern Africa to examine the increase in forms of 'legal pluralism' with regard to land tenure which result from migration and the interaction between migrants and local communities. The argument is made that the primary land tenure issues that will develop with increased rural migration in the developing world will be associated with a significant increment in legal pluralism in land tenure--or, multiple operative notions about resource use, access, and claim. Land tenure related impacts on environmental change will to a significant degree be associated with this pluralism, and as a result how states are prepared to contend with pluralism will become an important concern. The availability of legislative tools along with the ability and willingness of states to employ these, will impact how conflictive situations of legal pluralism over land resources become, and their overall impact on the resources needed for food security, development and conservation.

Subsequent to a brief introduction to legal pluralism, the bulk of the paper examines several of the more important ways that legal pluralism in land tenure develops in a migration context. This is followed by a brief discussion of the environmental impacts associated with tenurial pluralism, and finally the constraints involved in national level legislative response. 


\section{Legal Pluralism and Land Tenure}

Legal pluralism as a domain of legal studies has developed quickly in recent years, with issues of land tenure occupying a significant place in this progress (e.g., Benda-Beckmann 1995; Galanter 1981; Merry1988; Moore 1973; Griffiths 1986; Lund 1998; Prill-Brett 1994; Vel 1992). Important definitions of legal pluralism range from pluralism in the juristic sense, when a state brings about different laws for different groups of people (Merry 1988), to claiming that all societies are legally plural especially in less formal ways, in that making rules, obtaining compliance, and punishing rule breakers exists in a wide variety of societal subgroups (Abel 1982; Henry 1985). Much important research has focused on this informal domain, which recognizes legal pluralism as multiple, nonjuristic, alternative, forms of "normative ordering" (e.g., Merry 1988; Griffiths 1986). Griffiths (1986) notes that the law "which is actually effective on the 'ground floor' of society is the result of enormously complex and usually in practice unpredictable patterns of competition, interaction, negotiation, isolation, and the like," such that "the legal organization of society is congruent with its social organization."

Of particular utility in a migration context, is the semi-autonomous social fields approach described initially by Moore (1973), in which separate social fields of 'legality' interact over time and space. This interaction can take a number of paths from eventual reconciliation between fields, to increasing separation or multiplication of fields, depending on the nature of the interaction and associated resource-related, socio-political, and economic forces. Moore (1973) further articulates the role of semi-autonomous social fields in the way individual and group behavior and the processes of interaction within and between fields determine what 'law' is operative in a given space and time. Griffiths (1986) builds on Moore's (1973) work, noting that it is to a large degree the network of rights and obligations in human relationships which constitutes a 'legality' within a social field.

Land tenure in a very fundamental way is a system of rights and obligations in human relationships (Migot-Adholla and Bruce 1994). Legal pluralism in land tenure signifies the different sets of rights and obligations regarding land resources, as these reside within multiple social fields or normative orders. One of the most common examples of legal pluralism regarding land occurs in much of the developing world, where, due to the existence of both customary and formal tenurial systems, legal pluralism in land is an approach to practical governance. One the other hand one of the most aggravated examples of incompatible and confrontational legal pluralism regarding land exists in the Middle East, where the Israeli-Palestinian lands issue has vexed attempts at peacemaking for some time.

In a migration context, tenurial pluralism emerges as features of pre-migration tenure systems are shaped by the experiences of dislocation, migration, and attempts at settlement in new locations. This provides for a wide variety of approaches to accessing land 
resources in new locations with different political, social, cultural, and physical environments. At the same time non-migrant local communities that experience large influxes of migrants can abandon features of their own land tenure systems that others (migrants) are not following, and likewise pursue alternative modes of land access, use, claim, and dispute resolution. Important here is the role of tenure security. The search for tenure security in a physical, political, and socio-economic environment that is new and unfamiliar is an important driver in the search for alternative ways of configuring property rights; and an important factor in the development of legal pluralism. This search can be particularly robust when food insecurity and conflict are compounding influences--an important consideration given that most migrants are poor and lack the means to provide for near-term food security (Ghimire 1994). Tenure insecurity can be significantly aggravated by the lack of dispute resolution institutions able to operate between different notions of tenure, and seen as legitimate, effective, and enforceable by the parties concerned (Unruh 1997a, 1995b).

\section{Development of Legal Pluralism in Land Tenure}

\section{Rights and Obligations in Land Tenure}

Dislocation and migration profoundly change relationships between people--especially dislocation that results from severe circumstances (e.g., extreme food insecurity, resource scarcity, etc.) and migration experiences which are of long duration. Because of the importance of the spatial aspect in migration, established rights and obligations regarding land, property and resources are at the forefront of change. The socio-spatial repercussions and the subsequent reduction in the relevance of specific administration, enforcement, and other property-related institutions and norms, result in altered relationships between people, land areas, land uses, production systems, and population patterns. In essence, migration and its repercussions reconfigure the network of social relations upon which all land tenure systems--and hence agricultural and other land-based resource use systems--depend. Such changes in social relations as they affect land tenure become operative through specific interrelated processes. While these can be numerous, this section examines five of the more pervasive processes that change rights and obligations in land tenure and result in the development of multiple normative orders regarding tenure.

\section{Dislocation}

\section{Physical Separation and Status Change}

Population dislocation plays a primary role in the development of legal pluralism with regard to land. Physical separation of people from established home areas and ways of land use and tenure, can be the first and most dramatic step toward the development of a changed approach to land rights. Physical separation changes, terminates, or puts on hold prevailing social rights and obligations regarding land and property, especially where actual occupation, or social position forms the basis or a significant aspect of claim and use rights. This change occurs primarily because community members are no longer physically present to exercise rights and obligations. For those who are not dislocated or choose not to migrate, alternative ways of viewing land can move forward quickly, especially if 
marginalized sectors within a community see an opportunity to enhance rights. For migrants, land must usually be sought elsewhere especially for agricultural populations, but with an approach to access and claim to land resources different from what prevailed in a home area. This comes about with a change in status as community members become dislocatees, migrants, squatters, female-headed households, and refugees in new locations. Most African populations for example rely on relatives and other community members for security of person and property and for assistance in dispute resolution involving these. In circumstances involving dislocation and migration however, many variables serve to rework or reconfigure this construct, especially if the destination area has little or no community entry. Affected customary populations (both migrating and receiving) can move to establish alternative land tenure arrangements that follow newly emerging situations and norms, or pursue variations of old arrangements which will work under prevailing circumstances. The direction that this emergence takes and how rapidly it occurs can depend to a significant degree on experiences associated with dislocation, migration, and reception.

\section{Return to Area of Origin}

Return to a home area subsequent to dislocation can provide for additional opportunities for the development of legal pluralism. Relevant to the idea of 'return' is the potentially significant resistance and animosity toward returnees by community members who did not migrate. Such animosity can be pronounced when alternative ideas regarding land tenure are brought back with returnees, particularly when these ideas involve a perceived reduction in rights and/or power for those who stayed. Also relevant to 'going back' are the presence and activities of other actors--squatters, large landholders, commercial interests--all of whom may seek access to lands thought to be unoccupied or abandoned. Krznaric (1997) observes how dislocation and migration influenced the development of legal pluralism over land within returning groups of Guatemalan migrants versus those who stayed, due to the migrant's raised political awareness during their exile in Mexico. In Guatemala such raised awareness, itself different for different groups of dislocatees, was the result of the opportunity to advance certain interests suppressed under the predislocation community political arrangement--such as those of women and lower socioeconomic strata. An organizational capacity also emerged within some sectors of the Guatemalan refugee returnee community that adhered to a transnational language of rights (human rights, refugee rights) that was appropriated and used by groups of returnees. Hammond (1993) notes similar contrasts for Nicaragua and El Salvador, and Unruh (1997b) describes for Mozambique the difficulties in re-accessing home areas occupied by squatters and large commercial cotton interests.

\section{Change in Penetration of the State}

State Lands Administration

Dislocation and migration necessarily result in a change in the influence of state institutions and state law on populations, with the overall effect spatially variable. 
Subsequent to a dislocation event, the state's land administration institutions in areas of dislocation can be rendered much less influential, and rules unenforceable as pre-existing relationships with the state are disrupted. This can occur in several ways: (1) land records pertinent to affected areas of the country (both dislocating and receiving) become outdated as land and property transactions take place and go unrecorded; (2) a general recognition emerges by the dislocated population (and frequently the host population) of the unworkability of state land administration as a national institutional endeavor which serves their interests as migrants (or hosts); (3) in the context of a resurgence in the use of certain traditional norms in substate groups (frequently tied to identity); and, (4) increasing numbers of migrants and members of local host communities abandon the state tenure system in favor of alternatives, which then acts to further subtract adherents to state law in a 'momentum effect.' If dislocation is due to conflict and involves the state, then the influence of the state can be reduced considerably as the legitimacy of the national formal land tenure system is compromised. In such a case the derivation and pursuit of alternative forms of property rights arrangements can occur with considerable energy in the context of opposition to the state. At the same time the weakening or subordination of the state may have the effect of encouraging land grabbing by urban based elites. This can Take place as state controls diminish and those in a position to do so use the instruments of the state with greater ease to obtain land--in a form of legal pluralism derived from a changed position of the state with regard to property rights.

In Somalia, the complete reduction of state power and the search for order has led to the installation of Islamic Shari' a courts for administration and enforcement of a number of aspects of society, including land and property rights and land dispute resolution (UNDP-EUE 1999). During Mozambique's RENAMO war, the dislocation and resulting migration of approximately half of the national population, together with forces associated with the war, resulted in a considerable reduction in the capacity of the state to administer land. This allowed not only the RENAMO opposition, but a variety of groups to exert alternative approaches to land access, claim, and use. At the same time, many non-migrant communities in Mozambique refocused their attention on their own traditional ways of land tenure, dropping any recognition of state land administration that existed prior to the war. In some cases this allowed the occupation, or re-occupation, of lands formerly seized by the state or commercial interests (Unruh 1997b).

In a different effect on the state Mbembe (1999) observes that the efforts of the international conservation community have been significantly successful in moving large areas of land from effective state control, to extra-territorial status. This influences the development of legal pluralism both in the dislocation of local inhabitants, and the duality of state versus international territorial control.

\section{Land Related Grievances and the State}

Pre-dislocation ideas of the 'unjustness' in the way the state dealt with land rights for a population can constitute an important force in the reduction of state penetration in land 
issues during migration scenarios. Such ideas can range from simple disappointment in or distrust of the state and its ability, willingness, or bias in handling land issues, to the perception of the state as the enemy. The latter can be especially powerful if there exists an accumulation of land-related grievances against the state brought on by land alienation and discrimination, corruption, state intervention in agricultural production, dislocating agricultural or population programs (e.g., villagization), and heavy-handed approaches to enforcement of state decisions and prescriptions regarding land issues. In aggregate, this can result in what Ranger (1985) calls a "historical consciousness of grievances" with regard to land rights issues; these can become especially pronounced if grievances merge with other issues not necessarily related to land. In these cases dislocation and migration become an opportunity to derive and/or pursue alternative normative orders regarding land access and use. Such alternatives, once developed, can persist with considerable tenacity, justifying themselves by appeals to perceived historical wrongs done to certain groups (Merry 1988). De Soto and del Castillo (1995) note that land grievances had been at the core of the Salvadoran friction since the colonial era, and were some of the primary causes of the conflict in the 1980s. This was also the case in Zimbabwe's liberation war regarding land expropriations by the Rhodesian state (Ranger 1985), and in both Mozambique's RENAMO war and Ethiopia's Derg war as a result of government villagization programs. Variants of such conditions also prevail for more recent problems in southern Mexico, and in the way the land issue has been handled over the course of the conflict in the Middle East.

\section{Interventions}

Government and international donor interventions in migration scenarios can contribute significantly to the emergence of tenurial legal pluralism. In attempts to mitigate environmental degradation associated with migration, intervention programs can encourage migrants to plant trees (Ghimire 1994) or construct anti-erosion and water catchment installations, etc.--all of which can be seen by local non-migrant populations as attempts to claim land, and can in fact be used as such. Ghimire (1994) observes however that interventions such as tree planting can be more successful if migrants are first provided with secure access to land. Such an arrangement would be an explicit promotion of legal pluralism by an intervention intended specifically to both assist migrants and mitigate resource degradation.

\section{Flight from the State}

In broader fashion, migration plays an operative role in what Mbembe (1999) calls, for Africa, the current "flight from the state." Mbembe observes that a pronounced reconfiguring of the African continent is underway due to the effects of demography, urbanization, military, economic, and religious factors in which migration plays a primary functional role in bringing members of different groups into contact. In this pervasive scenario, different forms of political and social orders are emerging which bypass the state system. For land tenure, this means that forms of formal tenure connected to the state may increasingly be only one of several approaches to tenure rights which emerge through processes of migration. Nigeria provides an important example, where localities answer to 
a wide variety of jurisdictions and authorities that span a spectrum of government, ethnic, traditional, and religious authorities (Mbembe 1999). Migration is the operative process which brings subjects of these authorities and notions of legitimacy into close contact, resulting in a variety of conflicts. Often these are explicitly over land and resource access, with often no dispute resolution institutions operable between different and often competing notions of tenure.

Mbembe (1999) as well notes that the increasing number of migrants to different locations in Africa is providing for an "extraordinary rise in xenophobia." Such an effect can translate readily into a land tenure context, where attachments to land derive legitimacy from notions of insider - outsider in a variety of configurations. This, together with a reduction in state power, can bring pluralism to the fore in a variety of ways.

\section{Identity Change}

For considerable numbers of people who find themselves in migration scenarios, identity can become intricately bound up in land occupation, access, or perceived rights to specific lands in very powerful ways. Smith (1988) notes, that "the ethnic 'self' remains the fundamental territorial 'self' in Africa." In many cases the existence of ethnic, religious, geographic, or other identities to which primary attachments persist, can be based on connections to land, home area, or territory (Unruh 1998). Dislocation from home areas can result in a relative rise in the influence of identity-based attachments to land, especially if there is an identity component to the dislocation event, and destination locations for migrants become problematic for reasons involving identity (Ibrahim 1998).

Ibrahim (1998) notes that "the assertion of a person's identity is intended to give meaning to an encounter with others." The definition of identity in a context of migration can be predicated on how an individual or group see themselves with respect to other groups. Thus, approaches to land employed by one group in a migration context can be purposefully rejected by another, leading to a situation of opposed legal pluralism over land in destination areas. As the identities of those involved in migration develop and take on enhanced definition, or redefinition (Ibrahim 1998), approaches to land issues will reflect this and can become a prominent feature in pluralistic approaches to tenure.

Notions of identity can also involve land claim justification based on earlier historical occupation of areas that migrants can then seek out as destination locations, supported by oral histories that can be traced back through time into mythologies about how various peoples came to exist in an area and in the world (Comaroff and Simon 1977). Such justification can gain renewed strength during migration, and the pursuit of a 'return' to historical lands or territory--from which groups were expelled or departed, recently or long ago--can become a priority in a migration event. In some cases, such a situation can be seen as a singular opportunity to regain historical lands.

\section{Changes in Legitimacy and Evidence}

Claims to land, property, and territory are based on the perception of legitimacy in various 
forms. In a migration context legitimacy in land tenure becomes significantly problematic, as migrant groups emphasize, modify and derive notions of legitimacy which will allow access and use of land resources. The possession of evidence to prove and support rights of access and claim to land resources is a fundamental feature of land tenure systems. While formal tenure regimes hold the document to be the primary form of evidence, customary tenure systems and normative orders regarding land contain a wide variety of informal evidence that derives legitimacy and authority from relevant customary social and cultural features. During the course of dislocation and migration, evidence and legitimacy of evidence is subject to considerable change, primarily due to the role that community plays in determining what evidence is regarded as legitimate (Unruh 1997a). In one sense the boundary of a legal field (Griffiths 1986) with regard to a set of normative rules regarding land, can exist between those who do and do not regard certain forms of evidence as legitimate.

Shipton (1994) notes that within the administration of land (both formal and customary) the question of who controls the "language," and the "translations" of reality into legitimate evidence and how land is dealt with (demarcations, transfers, inheritance, access, etc.) becomes critically important (also Murphy 1990). Such control over what is or becomes evidence, legitimizes or de-legitimizes units of aggregation, kinds of rights, transactions, rituals, and ways of land use (Shipton 1994). Thus competition and confrontation over who exercises this control with regard to a specific land area, or specific rights within an area, can influence the development of legal pluralism. This occurs as some claimants find themselves with evidence different from that considered legitimate or possessed by others as dislocation and migration scenarios reconfigure the important aspects of evidence (e.g., community, occupation, relevant cultural-ecological features, customs, ways of administration, etc.). The same effect can manifest itself in a more nuanced fashion as the relative value of pre-existing evidence can shift to reflect changed circumstances (Unruh 1997a). This was the case in Mozambique, where, because land rights for the customary tenure system were bound up in historical interconnections of community interaction regarding land, and locally legitimate evidence of rights, migration resulted in a shift of legitimate evidence for many affected groups (emergence of alternative norms). This occurred as changes in specific evidence and community interaction regarding this evidence meant that shifts in the availability and legitimacy of evidence occurred. As a result 'social' customary evidence such as testimony, community and lineage membership, and history of occupation were significantly devalued due to widespread dislocation and migration. At the same time, the existence of permanent, physical investments in land, such as agroforestry trees, greatly increased in value as evidence (Unruh 2001).

\section{Processes Associated with Destination areas}

Tenure Insecurity as a 'pull' factor

The character of destination areas can exert considerable influence in the development of legal pluralism involving migrants--beginning with the relative degree of attraction to a destination area. In a study by Amacher et. al., (1998) land tenure insecurity was found to be a primary factor in selection of destination sites by migrants in the Philippines, with 
similar examples elsewhere in Asia. Migration destinations in this context can often be: (1) at the frontier of development, (2) in marginal lands, (3) where the state has neglected development or land tenure, or (4) where political instability has likewise caused tenure insecurity (Amacher et al 1998; Myers 1997). Such situations are seen as attractive opportunities for migrants in that they represent the possibility for pursuing various forms of claim for themselves, however temporary or unofficial (Amacher et al 1998).

Pre-migration tenure insecurity in such locations can often be the result of forms of tenurial pluralism to begin with. This can be the case when lands are claimed by both the state and local communities, or there is confusion over what rights different groups have. Conversely the opportunity for migrants to pursue pluralistic forms of claim is much reduced in locations where the in-place local community has strong and secure tenure rights that are effective and enforceable.

An initial search for areas of tenure insecurity by migrants can then be followed by the search for tenure security once claims are made; and this can significantly fuel the development of legal pluralism. But with no specific way to obtain tenure security in such areas, a number of different approaches can be attempted by migrants. Local communities--tenure insecure themselves--can be quick to abandon or change ways of tenure in the face of significant migrant arrival, because there can be little reason to continue with rules that others are not following.

\section{Relationships Between Migrant and Host Communities}

The nature of the intersection between local and migrant communities is one of the more important sources of tenurial legal pluralism in a migration context. Although there is a significant literature concerning the interaction between migrant and host communities on a variety of topics (e.g., Kok 1989; Wilson 1992; Unruh 1993; Clay and Stokke 1991) land tenure repercussions remain largely unexamined. McGregor (1994) notes how migrant and local societies themselves are not homogeneous. As a result, how migrants interact with local communities will not be homogenous. Interaction can depend on a wide variety of factors, including the nature of arrival (timing, seasonality, and magnitude); the socio-economic status of migrants vis a vis the local community; food security; and similarities or differences in ethnicity, land use, and production systems. Ostrom et. al., (1999) make the point that if resource users are added rapidly such as through migration, similar understandings of resources, and resource use and access are unlikely to be shared between local communities and migrants. As well there is variability in assistance migrants can receive as internally displaced persons (IDPs) or refugees from local, regional, national, or international organizations, with such assistance frequently contentious with regard to local communities.

How migrants settle in destination areas can have a significant influence on the derivation of legal pluralism for both migrant and local communities. Different patterns can emerge from settlement in refugee camps or other concentrated areas, versus settling scattered within the host community, versus scattered in a wide rural area in and around the host 
area. Concentrated settlement of migrants due to security, humanitarian, or resource availability reasons can encourage forms of tenure that are more competitive and contentious (Ghimire 1994), and lead to spatially acute forms of resource degradation (land, fuelwood, timber, water, etc.) (McGregor 1994). Decisions about where government and donors locate concentrations of refugees are rarely made with local community consultation, compensation, or coordination, especially with regard to how land is accessed. Legitimacy in tenure and tenure security for migrants in such a situation is often derived from the presence of a government or international entity seeking to service concentrations of refugees or IDPs via the formal national tenure system (McGregor 1994). Meanwhile local communities often continue with customary tenure. Differences in tenure security between local and migrant communities in such a case can be significant.

Settlement of migrants in more dispersed fashion within a local community results in differentiated approaches to land tenure. While a good relationship between host and migrant populations may result in secure access to land based resources (Wilson 1992) this is frequently difficult to achieve. Migrants can derive their own forms of land access in reaction to rules of exclusion by local communities, or exclusion from the institutions which facilitate an equitable place in the local land tenure system. Often such rules of exclusion are constructed and enforced in an attempt by the local community to avoid resource degradation and a 'tragedy of the commons' scenario (Ostrom 1990). Such exclusion can often be facilitated by the weak position of migrants vis a vis local communities (socially, economically and politically) (Ghimire 1994). However with needs and desperation frequently high among migrants, alternative ways, reasons, and legitimacy can quickly be configured in reaction to exclusion, competition, and confrontation with local communities. Where migrants are able to engage local resource access and use arrangements, these can often be a subset of local rules, or special rules set up for migrants which provide for more limited rights. This is the case with refugee communities in western Tanzania, and internal migrants in Zambia.

\section{Environmental Implications}

While tenurial legal pluralism alone does not necessarily lead to resource degradation, the combination of migration and legal pluralism provides for situations that lack mitigating institutions and rules that can prevent environmental degradation. In part this can be due to the lag time between the arrival of migrants and any derivation of institutions and rules able to mitigate degradation. But as noted above, to a significant degree much about migration and the effects it has on local populations, regions, and countries effectively discourages the derivation of the necessary institutions, rules, and laws that would serve to mitigate degradation.

Environmental degradation in this regard involves four primary interrelated processes. The first comprises the repercussions of tenure insecurity. Without secure tenure, migrants and the local communities affected tend to pursue more extensive cultivation and extractive practices. When this occurs on more marginal and fragile lands, degradation can be much 
more pronounced. Lands that are arid or semi-arid, have steep slopes, and are otherwise marginal for agriculture or pastoralism are especially susceptible to such degradation, and as noted above can be attractive to migrants (Amarcher et. al., 1988).

Second, migrants often face tenure regimes in developing countries that encourage deforestation and land clearing (Southgate 1990). The removal of trees and other vegetation is often a prerequisite for establishing claim and rights to land, and coupled with tenure insecurity in destination locations and a local institutional ability to effectively deal with tenure problems associated with migrants, can lead to significant deforestation (Southgate 1990).

Third, when use rights are a significant aspect of claim for migrants, continuous use of agricultural lands via cultivation and grazing in order to maintain rights within various tenurial constructs can lead to significant degradation (Southgate 1990). In a modeling effort, Southgate (1990) notes that significant land degradation occurs in parts of the developing world where migrants arrive to engage in agriculture, specifically because acquiring property rights to 'idle' land entails both removing vegetation and continuous use of land resources. In such a case migrant non-access to local and/or formal ways of access, use, and claim can encourage continuous use of land.

Fourth, land resource degradation due to the effects of migration can itself have a significant role in the continued development of legal pluralism in land tenure. This is because as land resources in a given location become increasingly degraded and scarce, and competition and confrontation emerge as significant themes of interaction, different forms of tenure will be more vigorously attempted in order to improve tenure security. As well, any existing forms of legal pluralism can become more pronounced as competition along with the absence of mediating institutions, can serve to drive different tenurial normative orders into increasingly opposed domains.

\section{Can National Legislative Efforts Keep Pace?}

What are the prospects for national legislative efforts in the developing world to keep pace with the need to derive and implement formal legal constructs which can effectively manage emerging pluralism in land tenure due to migration, and hence mitigate resource degradation? Recent historical scenarios do not paint a promising picture (e.g., Odoul 2001). Migrants can find that even if lands are available, significant rights to resources--and hence tenure security--are unavailable for those not from the host country, region, or local community (Ghimire 1994; Kabera 1987). And legal pluralism in land caused by or aggravated by migration--much of which will be taking place across international borders--will pose particular problems in legislative terms. Significant 
incentives exist which discourage the derivation and implementation of legislation for resolving the dilemmas of tenurial legal pluralism in migration contexts. Host communities, regions, and nations most often receive migrants with significant reluctance, and usually view their residence as temporary (Ghimire 1994). As a result there can be little enthusiasm (locally or nationally) for deriving the legislative means to deal with land conflicts between different forms of tenurial normative orders involving migrants, especially if the state views alternative forms of tenure as detracting from the national land tenure project (Thiadens 2001). And international bodies can have very limited influence encouraging nations toward such legislation (Thiadens 2001).

In reality legislative trends in many developing countries are moving in the direction of laws which increasingly restrict formal legal options for migrants regarding important aspects of land tenure; including dispute resolution, access, and use rights. Such reluctance or inability by national governments to derive and implement legislation and institutions able to effectively deal with legal pluralism in land tenure will significantly compromise the 'adaptation' between formal and non-formal forms of tenure which Bruce (2000) highlights as a significant pattern in coming decades in the developing world.

However there are examples where problematic pluralism did not develop in migrant situations, providing an example where conditions can vary with different results. Tanzania has had varying experiences with refugees, some of these include allowing refugees to become citizens with full tenurial rights to lands in largely uninhabited regions of the country (Christensen 1985). As well some Burundi refugees who settled in what is now Congo were able to rent land from local landlords, in an example where host tenure rules were able to be of use to migrants (Ghimire 1994). And in Zambia internal migrants from the Gwembe valley to the general area east of Kafue National Park were able to work with local chiefs in the derivation of an alternative rights system which allows access to land, including inheritance. These examples illustrate that migration need not necessarily result in resource degradation and conflict. But unfortunately these cases are the exception and not the rule.

\section{A Look Forward}

Migration will increasingly be used as a primary coping and adaptation strategy in response to the effects of global environmental change--including climate change. As patterns and processes of rural to rural migration come to operate in an increasingly pervasive manner, especially in the developing world, patterns of legal pluralism in land tenure will become an important feature. Environmental repercussions will to a significant degree be linked to important aspects of this pluralism. Lands most susceptible to the effects of migration and the resulting legal pluralism will include marginal areas and lands that are for a variety of reasons already tenure insecure. While the derivation of the necessary institutions and legal means can show promise, current trends are not encouraging. Much in the way of policy research is needed in order to adapt to the effects 
of global environmental change in its different manifestations. Policy tools able to cope with the migration - tenurial pluralism - environment nexus will be part of this need, and a significant challenge to the international community.

\section{References}

Abel, R.L. 1982: The politics of informal justice, 2 Vols. New York: Academic Press.

Amacher, G.S., Cruz, W., Gerbner, D., Hyde, W.F. 1998: Environmental motivations for migration: population pressure, poverty and deforestation in the Philippines. Land Economics 74, 92-101.

Benda-Beckmann, F. von. 1995: Anthropological approaches to property law and economics. European Journal of law and Economics 2, 309-336.

Bruce, J.W. 2000: African tenure models at the turn of the century: individual property models and common property models. Land Reform 1, 17-27.

Clay, J. and Stokke, O. 1991: Food aid reconsidered: assessing the impact on Third World countries. London, UK: Frank Cass.

Comaroff , J. and Simon, R . 1977: The invocation of norms in dispute settlement. In Hamnet, I., editor, Social Anthropology and Law, London, UK: Academic Press.

Doos, B.R. 1994: Environmental degradation, global food production, and risk for large-scale migrations. Ambio 23, 124-130.

Galanter, M. 1981: Justice in many rooms: courts, private ordering and indigenous law. Journal of Legal Pluralism 19, 1-47.

Ghimire, K. 1994: Refugees and deforestation. International Migration 32, 561-569.

Griffiths, J. 1986: What is legal pluralism? Journal of Legal Pluralism 24, 1-52.

Hammond, J. 1993: War up-rooting and the political mobilization of Central American refugees. Journal of Refugee Studies 6, 104-122.

Henry, S. 1985: community justice, capitalist society and human agency: the dialectics of collective law in the cooperative. Law and Society Review 19, 303.

Ibrahim, F. 1998: Editorial: identities in sub-Saharan Africa. GeoJournal 46, 77-78.

IUCN. 2000: IUCN-CEESP Environment and Security Task Force Briefing. IUCN. 
Presented at the World conservation Conference, Amman.

Kabera, J.B. 1987: The refugee problem in Uganda. In Rogge, J.R. editor, Refugees, a Third World dilemma. New Jersey: Rowman and Littlefield.

Katon, B., Knox, A., Meinzen-Dick, R. 2001: Collective action, property rights, and devolution of natural resource management. Policy Brief Number 2, CGIAR Systemwide program on Collective Action and Property Rights, International Food Policy Research Institute.

Kok, W. 1989: Self-settled refugees and the socio-economic impact of their presence in Kassala, Eastern Sudan. Journal of Refugee Studies 2, 419-441.

Krznaric, R. 1997: Guatemalan returnees and the dilemma of political mobilization. Journal of Refugee Studies 10, 61-78.

Lund, C. 1998: Struggles for land and political power: on the politicization of land tenure and disputes in Niger. Journal of Legal Pluralism 40, 1-22.

Mbembe, A. 1999: Migration of peoples, disintegration of states: Africa's frontiers in flux. Le Monde Diplomatique, November.

McGregor, J. 1994: Climate change and involuntary migration: implications for food security. Food Policy 19, 120-132.

Merry, S.E. 1988: Legal pluralism. Law and Society Review. 22, 869-896.

Migot-Adholla, S.E. and Bruce, J.W. 1994: Introduction: are indigenous African tenure systems secure? In Bruce, J.W., and Migot-Adholla, S.E., editors, Searching for land tenure security in Africa. Dubuque Iowa: Kendall/Hunt Publishing.

Moore, S. 1973: Law and social change: the semi-autonomous social field as an appropriate field of study. Law and Society Review 7, 719.

Myers, N. 1997: Environmental refugees. Population and Environment 19, 167-182.

Murphy, A.B. 1990: Historical justifications for territorial claims. Annals of the Association of American Geographers 80, 531-548.

Odoul, R. 2001: Ethiopian refugees need not fear harassment in camps. The East African, July 2-8.

Ostrom, E. 1990: Governing the Commons: The evolution of institutions for collective action. Cambridge UK: Cambridge University Press. 
Ostrom, E., Burger, J., Fields, C., Norgaard, R.B., Policansky, D. 1990: Revisiting the commons: local lessons, global challenges. Science 284, 278-282

Prill-Brett,. 1994: Indigenous land rights and legal pluralism among Philippine Highlanders. Law and Society Review 28, 687-697

Ranger, T. 1985: Peasant Consciousness and Guerrilla War in Zimbabwe. London, UK: James Currey.

Schmeidl, S. 1998: Comparative trends in forced displacement. In: Hampton, J. editor, Internally displaced people: a global survey. London, UK: Earthscan Publications.

Shipton, P. 1994: Land and culture in tropical Africa: soils, symbols, and the metaphysics of the mundane. Annual Review of Anthropology 23, 347-377.

Smith, A.D. 1988: Toward a geography of peace in Africa: re-defining substate determination rights. In: Johnston, R.J., Knight, D.B., Kofman, E. editors, Nationalism, self determination and political geography. New York: Croom Helm.

de Soto, A., and del Castillo, G. 1995: Implementation of comprehensive peace agreements: staying the course in El Salvador. Global Governance 1, 189-203.

Southgate, D. 1990: The causes of land degradation along "spontaneously" expanding agricultural frontiers in the Third World. Land Economics 66, 93-101.

Thesihuesen, W. 1991: Implications of the rural land tenure system for the environmental debate: three scenarios. Journal of Developing Areas 26,1-24.

Thiadens, R. 2001: Ethiopian refugees need not fear harassment in camps. The East African, July 2-8.

United Nations Development Programme - Emergencies Unit for Ethiopia (UNDP-EUE). 1999: Horn of Africa the Monthly Review - Somalia: power of Islamic courts and Shari'a militia increasing. UNDP-EUE, Addis Ababa.

Unruh, J.D. 2001: Land dispute resolution in Mozambique: institutions and evolution of agroforestry technology adoption. CAPRi Working Paper 12. Washington DC: IFPRI.

Unruh, J.D. 1998: Land tenure and identity change in postwar Mozambique. GeoJournal 46, 89-99.

Unruh, J.D. 1997a: Post-conflict recovery of African agriculture: critical resource tenure in Mozambique. Ph.D. Dissertation. 
Unruh, J.D. 1997b: The role of land conflict and land conflict resolution in a peace process: Mozambique's return to agriculture. Refuge 16, 28-33.

Unruh, J.D. 1995a: Agroforestry, reforestry and the carbon problem: the role of land and tree tenure. Interdisciplinary Science Reviews 20, 215-228.

Unruh, J.D. 1995b: The relationship between indigenous pastoralist resource tenure and state tenure in Somalia. GeoJournal 36, 19-26.

Unruh, J.D. 1993: Refugee resettlement on the Horn of Africa: the integration of host and refugee land use patterns. Land Use Policy 10, 49-66.

Vel , J. 1992: Umbu hapi versus umbu vincent: legal pluralism as an arsenal in village combats. In von Benda-Beckmann, F. von, and Velde Mvan, der editors, Law as a resource in agrarian struggles, Wageningse Sociologisch Studies 33. Agricultural University, Wageningen.

Wilson, K. 1992: Enhancing refugees own food acquisition strategies. Journal of Refugee Studies 5, 226-247. 